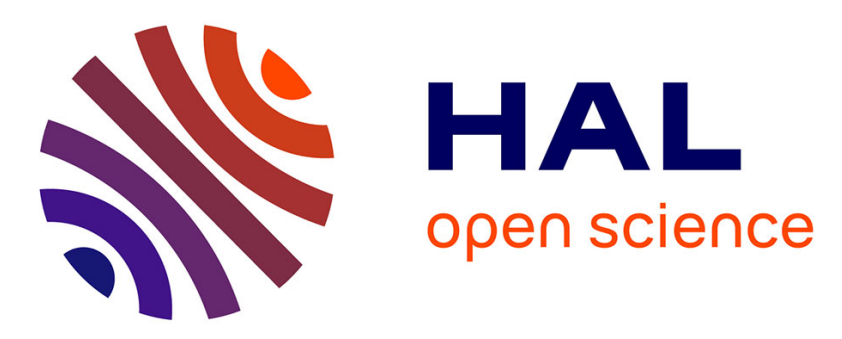

\title{
Attenuated behavioural responses to acute and chronic cocaine in GASP-1-deficient mice
}

Julien Boeuf, José Manuel Trigo, Pierre-Henri Moreau, Lucas Lecourtier, Elise

Vogel, Jean-Cristophe Cassel, Chantal Mathis, Paul Klosen, Rafael

Maldonado, Frédéric Simonin

\section{To cite this version:}

Julien Boeuf, José Manuel Trigo, Pierre-Henri Moreau, Lucas Lecourtier, Elise Vogel, et al.. Attenuated behavioural responses to acute and chronic cocaine in GASP-1-deficient mice. European Journal of Neuroscience, 2009, 30 (5), pp.860-868. 10.1111/j.1460-9568.2009.06865.x . hal-03037839

\section{HAL Id: hal-03037839 \\ https://hal.science/hal-03037839}

Submitted on 5 Nov 2021

HAL is a multi-disciplinary open access archive for the deposit and dissemination of scientific research documents, whether they are published or not. The documents may come from teaching and research institutions in France or abroad, or from public or private research centers.
L'archive ouverte pluridisciplinaire HAL, est destinée au dépôt et à la diffusion de documents scientifiques de niveau recherche, publiés ou non, émanant des établissements d'enseignement et de recherche français ou étrangers, des laboratoires publics ou privés. 


\section{Attenuated behavioural responses to acute and chronic cocaine in GASP-1 deficient mice}

Julien Boeuf ${ }^{1,}$, , José Manuel Trigo ${ }^{2,}$, Pierre-Henri Moreau ${ }^{4}$, Lucas Lecourtier ${ }^{4}$, Elise Vogel ${ }^{4}$, Jean-Cristophe $\mathrm{Cassel}^{4}$, Chantal Mathis ${ }^{4}$, Paul Klosen ${ }^{3}$, Rafael Maldonado ${ }^{2}$ and Frédéric Simonin ${ }^{1, \#}$

${ }^{1}$ Institut de Recherche de l'ESBS, CNRS - Université de Strasbourg, Bvd S. Brant 67412 Illkirch, France; ${ }^{2}$ Departament de Ciències Experimentals $i$ de la Salut, Laboratory of Neuropharmacology, Universitat Pompeu Fabra, Barcelona, Spain; ${ }^{3}$ Département de Neurobiologie des Rythmes, Institut de Neuroscience Cellulaire et Intégrative, UMR-7168 / LC2, CNRS - Université de Strasbourg, France; ${ }^{4}$ Laboratoire d'Imagerie et de Neurosciences Cognitives, Université de Strasbourg, France.

\#Correspondence : Dr Frédéric Simonin, Département Récepteurs et Protéines Membranaires, as above. Email: simonin@esbs.u-strasbg.fr

J.B. and J.M.T. contributed equally to this work

\section{Running title: Cocaine in GASP-1 deficient mice}

Pages : 32

Manuscript : 7400 words
Figures : 4

Abstract : 250 words
Tables : 1

Introduction : 503 words

Supporting informations: 2 figures and methods

Key Words: sensitization to cocaine locomotor effects, cocaine self-administration, striatum, dopamine receptors, receptor down-regulation. 


\section{Abstract}

G protein-coupled receptor (GPCR) associated sorting protein 1 (GASP-1) interacts with GPCRs and is implicated in their postendocytic sorting. Recently, GASP-1 has been shown to regulate dopamine $\left(\mathrm{D}_{2}\right)$ and cannabinoid $(\mathrm{CB} 1)$ receptors signalling suggesting that preventing GASP-1 interaction with GPCRs might provide a means to limit the decrease in receptor signalling upon sustained agonist treatment. In order to test this hypothesis, we have generated and behaviourally characterized GASP-1 knockout (KO) mice and have examined the consequences of the absence of GASP-1 on chronic cocaine treatments. GASP-1 knockout (KO) and wild-type (WT) mice were tested for sensitization to the locomotor effects of cocaine. Additional mice were trained to acquire intravenous self-administration of cocaine on a fixed ratio 1 schedule of reinforcement, and the motivational value of cocaine was then assessed using a progressive ratio schedule of reinforcement. The dopamine and muscarinic receptor densities were quantitatively evaluated in the striatum of WT and $\mathrm{KO}$ mice tested for sensitization and self-administration. Acute and sensitized cocaine-locomotor effects were attenuated in $\mathrm{KO}$ mice. A decrease in the percentage of animals that acquired cocaine self-administration was also observed in GASP-1 deficient mice, which was associated with pronounced down-regulation of dopamine and muscarinic receptors in the striatum. These data indicate that GASP-1 participates in acute and chronic behavioural responses induced by cocaine and are in agreement with a role of GASP-1 in post-endocytic sorting of GPCRs. However, in contrast to previous studies, our data suggest that upon sustained receptor stimulation GASP-1 stimulates recycling rather than receptor degradation. 


\section{Introduction}

G protein-coupled receptors (GPCRs) form one of the largest protein family encoded by the human genome (Vassilatis et al., 2003; Fredriksson \& Schioth, 2005). They are activated by a large variety of ligands and are involved in numerous physiological processes in the central nervous system. They are the most intensively studied targets for drug development, accounting for more than $30 \%$ of marketed small-molecule therapeutics used in humans (Hopkins \& Groom, 2002).

GPCRs undergo rapid desensitization and internalization upon stimulation. Following their endocytosis, they can be either recycled back to the cell surface or degraded by the lysosomal pathway. These phenomena are tightly regulated and are highly dependent on the primary structure of each receptor, particularly the $\mathrm{COOH}$-terminal intracellular tail. Arrestins and $\mathrm{G}$ protein-coupled receptor kinases are critically involved in desensitization and internalization of GPCRs (Moore et al., 2007). Much less is known about the mechanisms that govern the postendocytic sorting of these receptors. Several proteins that interact with the carboxyl-terminal tail of different GPCRs are critically involved in addressing receptors toward recycling or degradation pathways (Cong et al., 2001; Wang et al., 2002; Weinman et al., 2006). Amongst them, GPCR associated sorting protein 1 (GASP-1) has been shown to mediate postendocytic lysosomal sorting of GPCRs (Whistler et al., 2002).

GASP-1 is the first member of a family of ten proteins, which display a conserved carboxyl-terminal domain involved in the interaction with GPCRs (Simonin et al., 2004). GASP1 interacts in vitro with the carboxyl tail of numerous GPCRs and two conserved residues located within putative helix 8 of this region have been shown to be critical for this interaction (Simonin et al., 2004). These data suggest that GASP-1 could play a role in the postendocytic sorting of a 
wide range of GPCRs. Its functional implication in receptor down-regulation has been shown for several receptors (Whistler et al., 2002; Bartlett et al., 2005; Martini et al., 2007). In all cases, overexpression of a dominant negative mutant of GASP-1 prevented in vitro agonist-induced degradation of these receptors. Furthermore, anti-GASP-1 antibody feeding improved $\mathrm{D}_{2}$ receptor resensitization after agonist stimulation in ventral tegmental area slices (Bartlett et al., 2005), while viral overexpression of a GASP-1 dominant negative mutant in the dorsal horn of the spinal cord reduced the development of cannabinoid antinociceptive tolerance (Tappe-Theodor et al., 2007). These data led to the hypothesis that preventing GASP-1 interactions with GPCRs might provide a means to limit the decrease in receptor signalling upon sustained agonist treatment (Whistler et al., 2002; Bartlett et al., 2005; Tappe-Theodor et al., 2007).

In order to test this hypothesis we have generated and behaviourally characterized GASP-1 knockout (KO) mice. As GASP-1 has been shown to modulate dopamine receptor signalling, we have examined the consequences of the absence of this protein on chronic cocaine treatments. We have evaluated both the reinforcing properties of the drug in self administration experiments and sensitization to its locomotor effects. In addition, we have measured the levels of dopamine and muscarinic receptors in striata of these animals by radioligand binding experiments.

\section{Materials and methods}

\section{Drugs}

Cocaine hydrochloride was obtained from Ministerio de Sanidad y Consumo (Spain) and dissolved in sterile $0.9 \%$ physiological saline. 


\section{Animals housing and welfare}

Mice were housed by groups of five per cage with ad libitum food and water, in a temperature $\left(21 \pm 1^{\circ} \mathrm{C}\right)$ - and humidity $(65 \pm 10 \%)$-controlled room under a normal 12/12 $\mathrm{h} \mathrm{light/dark} \mathrm{cycle}$ (lights on from 08:00 to 20:00). In self-administration studies, mice were maintained in a reversed 12/12 h light/dark cycle (lights off from 08:00 to 20:00). Sensitization studies took place during the light phase, while self-administration studies were performed during the dark phase of the light/dark cycle. Mice were between 12 and 16 weeks old and weighed 25-30 $\mathrm{g}$ at the beginning of the experiments. Behavioural tests and animal care were conducted in accordance with standard ethical guidelines (National Institutes of Health, 1995; European Communities Directive 86/609 EEC), and approved by the local ethical committee (CEEA-IMAS-UPF). All behavioural experiments were performed under blind conditions.

\section{Production of Gprasp1 ${ }^{-1-}$ mice}

The Gpraspl mutant mouse line was established at the MCI/ICS (Mouse Clinical Institute Institut Clinique de la Souris, Illkirch, France; http://www-mci.u-strasbg.fr). To construct the targeting vector, two DNA fragments corresponding to the $5^{\prime}(4.1-\mathrm{kb})$ and 3 ' $(3.6-\mathrm{kb})$ homology arms were amplified by high fidelity PCR from 129S2/SvPas mouse embryonic stem (ES) cells genomic DNA. The amplified fragments were subcloned into a MCI proprietary vector upstream and downstream of a 1.9-kb Neomycin resistance cassette. The linearized construct was electroporated into 129S2/SvPas mouse ES cells. After neomycin selection, targeted resistant clones were identified by PCR using external primers and further confirmed by Southern blot analysis using a ${ }^{32} \mathrm{P}$-labeled Neo probe following Hind III (5') and Bgl II (3') digestions of the genomic DNA. A positive ES clone was microinjected into C57BL/6J blastocysts and gave rise 
to chimeric offspring, which in turn were mated with C57BL/6J mice. Agouti-coat pups were genotyped by PCR, showing the germline transmission. PCR analysis was done by using two sets of primers: a F1-R1 primer set, which allows to discriminate the wild-type (WT) allele by using a WT locus specific primer R1; and a F2-R2 primer set, which permits to discriminate the mutant allele by using a Neo specific primer F2. F1 and R2 primers are specific to the 5' and 3' homology arm, respectively, which are both present in WT and mutant alleles. F1-R1 and F2-R2 primer sets gave 288-bp and 710-bp PCR fragments, respectively. All mice used in this study were homozygous mutant mice and their wild-type littermates obtained from intercrosses between (129S2/svPas X C57BL/6J) F1 heterozygous female and wild-type males.

\section{Anti-GASP-1 antibodies}

Polyclonal antibodies directed against the 924-1395 AA portion of human GASP-1 were produced in rabbit (Antibody facility of The Institut de Génétique et de Biologie Moléculaire et Cellulaire, Illkirch, France; http://www-igbmc.u-strasbg.fr). The antibodies were purified by affinity chromatography on sepharose resin coupled with the purified antigenic portion of GASP1.

\section{The light/dark box test}

This test was used to assess the anxiety level of the mice under drug-free conditions. The apparatus consisted of two equal PVC boxes $(18.5 \times 18.5 \times 15 \mathrm{~cm})$, one opaque and the other transparent, connected with an opaque PVC tunnel $(5 \mathrm{~cm} \varnothing, 5.5 \mathrm{~cm}$ long) at the floor level. The transparent box was positioned $25 \mathrm{~cm}$ under a $100 \mathrm{~W}$ lamp. The mouse was initially placed in the dark box and the time spent in the lit box, as well as the number of transitions between the two boxes were recorded during $5 \mathrm{~min}$. 


\section{The free-exploratory test}

This test assessed anxiety and the exploration propensity. The apparatus consisted of a grey PVC box (30 $\times 20 \times 20 \mathrm{~cm})$ divided in $2 \times 3$ equal square units interconnected by small sliding doors. The mouse was left for $24 \mathrm{~h}$ in one half of the apparatus (3 units on one side) with fresh sawdust on the floor and free access to food and water. After the $24 \mathrm{~h}$ elapsed, the mouse was given access to the entire apparatus for $10 \mathrm{~min}$. The total number of units visited (locomotion), the time spent in the unfamiliar units and the number of rearings were recorded.

\section{Locomotor activity sensitization}

Protocol 1. The locomotor responses induced by cocaine $(20 \mathrm{mg} / \mathrm{kg}$, i.p.) were measured by using individual locomotor activity boxes $(9 \times 20 \times 11 \mathrm{~cm}$; Imetronic, Pessac, France) as previously described (Castane et al., 2002). The sensitization procedure was similar to the protocol previously described (Zhang et al., 2006) with slight modifications. In our study, animals ( $\mathrm{n}=10$ per group) were habituated for $1 \mathrm{~h}$ in the locomotor activity boxes. For the following 2 sessions, all mice received saline $(1 \mathrm{ml} / 100 \mathrm{~g}$, i.p. $)$, and their locomotor responses were recorded for $1 \mathrm{~h}$ after the injection to measure baseline motor activity. Mice were thereafter treated with cocaine (20 $\mathrm{mg} / \mathrm{kg}$, i.p.) or saline during 10 consecutive days. Five days after the last chronic administration (day 15), the expression of sensitization was evaluated with an acute challenge (cocaine $20 \mathrm{mg} / \mathrm{kg}$, i.p. or saline).

Protocol 2. In order to follow up sensitization and dose-response effects, i.p. injections of saline and cocaine were performed in the following order: injection $1=$ saline, injection $2=$ cocaine $(10 \mathrm{mg} / \mathrm{kg})$, injection 3 cocaine $(10 \mathrm{mg} / \mathrm{kg})$, injection 4 cocaine $(20 \mathrm{mg} / \mathrm{kg})$, injection 
5 cocaine $(20 \mathrm{mg} / \mathrm{kg})$. The first four injections were administered each $48 \mathrm{~h}$. Injection 5 was administered 10 days after injection 4 . Sensitization was determined as differences between activity levels recorded following injections 2 and 3. Possible dose-response relationships in sensitized animals were determined by differences between activity levels recorded after injections 3 and 4. The presence of stereotypies at the highest dose was evaluated on injection 5. Recording of locomotor activity started 1-5 min following treatment administration and was measured in Makrolon cages $\left(42 \times 26 \times 15 \mathrm{~cm}^{3}\right)$ in which mice $(\mathrm{n}=$ 15 per group) were placed individually one day before the beginning of the experiment. Two infrared beams, passing through each cage targeting two photocells, $2.5 \mathrm{~cm}$ above the cage floor level detected beam interruptions so longitudinal cage crossings could be determined and recorded by a microcomputer in 5-min intervals. Only the first postinjection $h$ was considered for data analysis. Following injection 5, the presence of the stereotyped behaviours turning, grooming, sniffing (up or down), digging, head wagging and rearing were scored 1 for occurrence and 0 for non- occurrence during 20-s intervals. Subsequently, ratings were analyzed as the mean number of stereotyped behaviours over the twelve 5-min intervals of the test. Locomotor activity was also recorded during injection 5.

Drug self-administration

Apparatus. Self-administration training and testing were performed in 16 operant chambers (Model ENV-307A-CT, Med-Associates, St. Albans, VT, USA), as previously described (Trigo et al., 2007).

Surgery. Mice ( $\mathrm{n}=20$ per group) were anaesthetized with a ketamine/xylazine mixture $(5: 1 ; 1$ $\mathrm{ml} / 100 \mathrm{~g}$ body weight, i.p.) and then implanted with an indwelling i.v. silastic catheter in the right 
jugular vein, as previously described (Trigo et al., 2007). After surgery, mice were individually housed. Potency of the catheters was evaluated periodically (once a week), and whenever drug self-administration behaviour appeared to deviate dramatically from the one previously observed, by infusing $0.1 \mathrm{ml}$ of thiopental $(5 \mathrm{mg} / \mathrm{ml})$ through the catheter. If prominent signs of anaesthesia were not apparent within $3 \mathrm{~s}$ of the infusion, the corresponding mice were removed from the experiment.

Self-administration procedure. Four days after surgery, mice were trained to nose-poke under a fixed ratio 1 schedule of reinforcement in order to receive cocaine $(1 \mathrm{mg} /(\mathrm{kg} *$ infusion $))$ for 10 consecutive days as previously described (Trigo et al., 2007). Stable acquisition of selfadministration behaviour was achieved when all of the following conditions were met: 1) less than $20 \%$ deviation from the mean of the total number of reinforcers earned in three consecutive sessions ( $80 \%$ stability), 2) at least $75 \%$ responding on the active hole, and 3) a minimum of 10 reinforcers earned per session. When stability had been acquired, mice were tested on a progressive ratio schedule of reinforcement, in this paradigm, the requirement to earn an injection escalated according to the following series: 1-2-3-5-12-18-27-40-60-90-135-200300-450-675-1000 as previously described (Trigo et al., 2006).

\section{Brain collection and total homogenates preparation}

Mice from both sensitization and self-administration studies were killed 60 min after the last session, and their brains were rapidly removed. Brain areas were dissected on ice, frozen on dry ice and stored at $-80^{\circ} \mathrm{C}$ until used. For each brain area, 3-5 tissue samples per group were pooled and homogenized (Ultra-Turrax DI 18 Disperser, IKA Werke GmbH \& Co., Staufen, Germany) for $30 \mathrm{~s}$ in 20 volumes (w/v) of ice-cold $50 \mathrm{mM}$ Tris- $\mathrm{HCl}$ buffer $(\mathrm{pH} 7.4)$, and washed twice by centrifugation $\left(20,000 \mathrm{xg}, 10 \mathrm{~min}, 4^{\circ} \mathrm{C}\right)$. Pellets were resuspended in fresh buffer and 
homogenized by $5-10$ strokes in a glass Potter apparatus. Protein concentrations were determined (BCA assay kit Pierce, Fisher Scientific Bioblock, Illkirch, France) and adjusted to $1 \mathrm{mg} / \mathrm{ml}$.

\section{Binding assays}

Muscarinic (M-like) receptor binding sites were measured using the non-selective ligand $\left[{ }^{3} \mathrm{H}\right]-\mathrm{N}$ methylscopolamine ([$\left.{ }^{3} \mathrm{H}\right]-\mathrm{NMS}, 78 \mathrm{Ci} / \mathrm{mmol}$, PerkinElmer, Boston, MA, USA) according to (Dombrowski et al., 1983), with minor modifications. Total homogenates (10 $\mu \mathrm{g} / \mathrm{assay})$ were incubated for $120 \mathrm{~min}$ at $20^{\circ} \mathrm{C}$ with $3 \mathrm{nM}\left[{ }^{3} \mathrm{H}\right]-\mathrm{NMS}$ in $150 \mathrm{mM}$ sodium phosphate buffer $(\mathrm{pH}$ 7.4) in a final volume of $0.2 \mathrm{~mL}$. Non-specific binding was assessed in the presence of $10 \mu \mathrm{M}$ atropine.

Dopaminergic receptor binding sites were measured using $\left[{ }^{3} \mathrm{H}\right]-\mathrm{SCH} 23390\left(\mathrm{D}_{1}\right.$-like $)$ and $\left[{ }^{3} \mathrm{H}\right]-$ spiperone ( $\mathrm{D}_{2}$-like) as previously described (Madras et al., 1988; Xu et al., 1991). Total homogenates $(50 \mu \mathrm{g} /$ assay $)$ were incubated for $60 \mathrm{~min}$ at $37^{\circ} \mathrm{C}$ with $6 \mathrm{nM}\left[{ }^{3} \mathrm{H}\right]-\mathrm{SCH} 23390(85$ $\mathrm{Ci} / \mathrm{mmol}$, PerkinElmer) for $\mathrm{D}_{1}$-like receptors or $3 \mathrm{nM}\left[{ }^{3} \mathrm{H}\right]$-spiperone (15 Ci/mmol, PerkinElmer) for $\mathrm{D}_{2}$-like receptors in $50 \mathrm{mM}$ Tris-HCl buffer ( $\mathrm{pH} 7.4$ ), $150 \mathrm{mM} \mathrm{NaCl}, 5 \mathrm{mM} \mathrm{MgCl} 2,1 \mathrm{mM}$ EDTA in a final volume of $0.2 \mathrm{~mL}$. For $\mathrm{D}_{2}$-like, $5 \mu \mathrm{M}$ mianserin was added into the buffer to block serotonergic sites. Non-specific binding was defined with $10 \mu \mathrm{M}(+)$ butaclamol.

After the incubation, samples were filtered through $0.5 \%$ polyethylenimine pre-incubated glass fibre filters (Whatman GF/B, GE Healthcare, Saclay, France) in a cell harvester apparatus (Brandel, Alpha Biotech Ltd., London, UK). Filters were washed three times with $4 \mathrm{~mL}$ of icecold sodium phosphate or Tris- $\mathrm{HCl}$ buffer for muscarinic and dopaminergic receptors binding assays, respectively. Radioactivity was measured by scintillation counting (Packard 2100 TR, PerkinElmer). 
Statistical analysis

Locomotor activity data in protocol 1were analyzed by two-way repeated measures ANOVA. Differences between saline and cocaine treatments for each genotype were analyzed by one-way ANOVA when appropriate. In protocol 2, due to heterogeneity of the variances, the locomotor scores were first transformed in their square root as previously described (Wallenstein et al., 1980) and then analyzed using a three-way ANOVA (genotype $x$ drug $x$ time). Stereotypies were analyzed using a two-way ANOVA (genotype x time) without prior transformation of the scores. Multiple comparisons were performed using Newman-Keuls test when appropriate. For cocaine self-administration studies, two-way repeated measures ANOVA was first used. Discrimination between the active and the inactive holes for each genotype, the data of light/dark box and free-exploratory tests, and the data of the PR studies were analyzed using one-way ANOVAs. Differences in the percentage of mice reaching the criteria for stable acquisition of self-administration behaviour were analyzed using Pearson chi2. Binding data were analyzed using one-way ANOVA and unpaired two-tailed $t$-tests. $P<$ 0.05 was considered to denote statistical significance.

\section{Results}

\section{Generation and behavioural characterization of GASP-1 deficient mice}

In order to selectively knockout the G protein-coupled receptor associated sorting protein-1 gene (Gprasp1), we constructed a targeting vector in which exons 5 to 11 of GASP-1 were replaced by a neomycin cassette (Fig. 1A). Correct targeting of the construct was confirmed by PCR (not 
shown) and Southern blot analysis of neomycin resistant ES cells (Fig. 1B). Targeted ES cells were further used to generate GASP-1 deficient mice. Germline transmission of the mutation was confirmed by PCR analysis of mouse genomic DNA (Fig. 1C). Finally, western blot analysis showed that GASP-1 was absent in brain of GASP-1 homozygous mice (Fig. 1D). GASP-1 KO animals were healthy and had no gross abnormalities. There were no obvious differences in number of males and females in the offspring of mutant animals. Moreover, targeted deletion of Gprasp1 did neither alter the overall brain architecture nor the general behaviour of mice in home cage conditions. Anxiety-like and exploratory activity of KO mice were evaluated using the light /dark box and the free-exploratory tests, respectively. In the light/dark box test, the time spent exploring the lit box and the number of transitions between the two compartments were similar for the KO mice and their WT littermates (time in lit box: 26.6 $\pm 8.1 \mathrm{~s}$ for GASP-1 and $27.1 \pm 15.2 \mathrm{~s}$ for $\mathrm{WT}, \mathrm{F}_{(1,27)}=0.002$, NS; number of transitions: $3.4 \pm$ 0.9 for $\mathrm{KO}$ and $2.5 \pm 1.0$ for $\left.\mathrm{WT}, \mathrm{F}_{(1,27)}=0.45, \mathrm{NS}\right)$. In the free-exploratory test, the time spent exploring the new environment was similar in both groups $(211.6 \pm 43.0 \mathrm{~s}$ for $\mathrm{KO}$ and $278.6 \pm 38.6 \mathrm{~s}$ for $\mathrm{WT}, \mathrm{F}_{(1,26)}=1.34$, NS). However, GASP-1 mice showed a non significant tendency to decrease locomotion and made less rearings than the wild type mice (locomotion: $90.2 \pm 13.2 \mathrm{~s}$ for $\mathrm{KO}$ and $131.7 \pm 17.4 \mathrm{~s}$ for $\mathrm{WT}, \mathrm{F}_{(1,26)}=3.59$, NS; rearings: $14.1 \pm 3.4 \mathrm{~s}$ for $\mathrm{KO}$ and $27.6 \pm 5.6 \mathrm{~s}$ for $\left.\mathrm{WT}, \mathrm{F}_{(1,26)}=4.25, P<0.05\right)$. These data indicate that GASP-1 KO mice do not differ from their wild type controls in the time spent exploring a stressful, unknown environment (light/dark box test) or an unfamiliar environment in a non-constraining situation (free-exploratory test), respectively. Only a slight decrease at spontaneous vertical locomotion was revealed in these mutant mice. Thus, GASP-1 deficiency does not seem to affect anxiety related behaviours in mice. In addition, 
preliminary data suggest that spatial memory was not affected in GASP-1 mutant mice (Mathis C. personal communication)

Gprasp2 gene expression in GASP-1 KO mice

Since the second member of the GASP family, GASP-2, displays close sequence homology with GASP-1, the consequences of Gprasp1 deletion on Gprasp2 expression was assessed by in situ hybridization. No obvious differences were revealed in Gprasp2 expression level between WT and KO mice (see Supporting information Fig. S1 and methods). These results suggest that the absence of GASP-1 was not compensated by changes in expression or distribution of GASP-2.

Behavioural responses of GASP-1 KO mice upon cocaine treatment

Dopamine $\mathrm{D}_{2}$ receptors have been previously shown to interact with GASP-1 and disruption of this interaction in primary neurons facilitated recovery of $\mathrm{D}_{2}$ responses (Bartlett et al., 2005). We therefore examined the behavioural responses of GASP-1 KO mice to cocaine treatment in two different paradigms, locomotor sensitization, in which cocaine was administered by noncontingent injections, and self-administration, which corresponds to a daily contingent administration of the drug.

In the locomotor sensitization paradigm (protocol 1, see methods), mice received a daily injection of cocaine $(20 \mathrm{mg} / \mathrm{kg}$, i.p.) or saline for 10 consecutive days, and the effects of an additional challenge to cocaine were evaluated at day 15 (Fig. 2). A progressive reduction of the locomotor activity was observed in both WT and KO mice during the successive habituation sessions. Thus, WT mice reduced the horizontal activity in 45.9 and $62.9 \%$ during the second and third habituation sessions, respectively, when compared to the first 
day. Similarly, reductions of $\mathbf{4 3 . 0} \%$ and $66.6 \%$ (respectively) were observed in KO mice. This progressive reduction of the locomotor activity was also observed for vertical activity. WT mice showed reductions of 59.3 and $64.6 \%$ whereas in $\mathrm{KO}$ mice these reductions were of 70.0 and $77.1 \%$ during the second and third habituation sessions, respectively, when compared to the first day. The first acute cocaine administration significantly increased locomotor activity only in $\mathrm{WT}\left[\mathrm{F}_{(1,19)}=17.375, P<0.01\right]$, but not in $\mathrm{KO}$ animals (comparisons to saline groups). Successive injections of cocaine significantly increased the locomotor response with respect to the first acute administration, in both genotypes, although a more reliable response was revealed in WT than in KO mice (significant locomotor enhancement for 7 days out of 10 in WT mice versus 4 days out of 10 in $\mathrm{KO}$ mice, data not shown). At day 15, a significant increase in locomotion compared to the response after the first cocaine injection, was only revealed in WT mice $\left[\mathrm{F}_{(1,9)}=8.479, P<0.05\right]$ (Fig. 2).

We then performed a second experiment in which the first two doses of cocaine that were injected were decreased from 20 to $10 \mathrm{mg} / \mathrm{kg}$ (protocol 2 , see methods). Two-way ANOVA for beam interruptions showed significant overall effects of genotype $\left[F_{(1,26)}=4.4\right.$, $P<0.05]$, dose $\left[\mathrm{F}_{(3,78)}=18.3, P<0.001\right]$ and time $\left[\mathrm{F}_{(2,52)}=121.5, P<0.001\right]$ and a significant interaction between them $\left[F_{(6,156)}=3.3, P<0.01\right]($ Fig. 3A). Overall activity scores increased following the three injections of cocaine $(P<0.05$ in all cases $)$. Interestingly, when compared to their WT counterparts, KO mice showed lower locomotor activity levels during the first 20-min post-injection interval that followed both the second injection of 10 $\mathrm{mg} / \mathrm{kg}$ cocaine and the subsequent one of $20 \mathrm{mg} / \mathrm{kg}$. For the number of cage crossings, twoway ANOVA showed overall effects of genotype $\left[\mathrm{F}_{(1,26)}=5.6, P<0.05\right]$, dose $\left[\mathrm{F}_{(3,78)}=4.5, P\right.$ $<0.005]$ and time $\left[\mathrm{F}_{(2,52)}=28.4, P<0.001\right]$ but no significant interaction between them $\left[\mathrm{F}_{(6,156)}=1.5, \mathrm{NS}\right](\mathrm{Fig} .3 \mathrm{~B})$. Control animals receiving only saline in the first experiment did 
not display any variation of locomotor activity and a saline group was not included in the second experiment.

Two-way ANOVA for overall stereotypy scores, recorded after the fourth injection of cocaine $(20 \mathrm{mg} / \mathrm{kg})$, showed no significant effect of genotype $\left[F_{(1,26)}<1.0\right.$, NS] (see supporting information Fig. S2) but a significant effect of time $\left[\mathrm{F}_{(11,286)}=3.06, P<0.001\right]$, and no significant interaction between both factors $\left[F_{(11,286)}<1.0\right.$, NS]. Following injection 5 , overall activity levels were again significantly higher in WT than in KO mice $(P<0.05$; see supporting information Fig. S2). Taken together, these data indicate that both the acute locomotor response and sensitization to cocaine are significantly decreased in GASP-1 KO animals.

Cocaine reinforcing properties were evaluated in the self-administration paradigm. Both genotypes acquired and maintained a reliable operant response to self-administrated cocaine (1 $\mathrm{mg} /(\mathrm{kg} *$ infusion $))$, as shown by patent discrimination between the active and the inactive holes during the whole experimental sequence (Fig. 4A). For KO mice, two-way ANOVA showed a significant effect of hole $\left[\mathrm{F}_{(1,26)}=23.628, P<0.001\right]$ and of the interaction between these two factors $\left[\mathrm{F}_{(9,234)}=6.681, P<0.001\right]$ without significant effect of day $\left[\mathrm{F}_{(9,234)}=1.011\right.$, NS $]$. Twoway ANOVA in WT mice showed significant effect of hole $\left[\mathrm{F}_{(1,26)}=61.674, P<0.001\right]$ without significant effect of either day $\left[\mathrm{F}_{(9,234)}=1.272, \mathrm{NS}\right]$, or interaction between these two factors $\left[\mathrm{F}_{(9,234)}=1.216, \mathrm{NS}\right]$. Although both WT and KO mice consistently discriminate between the active and the inactive holes in this experiment, only $50 \%$ of the $\mathrm{KO}$ animals trained to selfadminister cocaine reached the acquisition criteria, whereas $86 \%$ of the WT mice reached these criteria. Pearson chi 2 analysis showed a significant difference in the percentage of acquisition between KO and WT animals $(\operatorname{chi} 2=4.094, P<0.05)$. Mean time to achieve the acquisition criteria was similar in both genotypes $(3.33 \pm 0.64$ days in WT and of $3.28 \pm 0.83$ 
days in KO). Differences in the number of cocaine infusions obtained by both genotypes were analyzed using two-way ANOVA. A significant effect of day was observed $\left[\mathrm{F}_{(9,252)}=2.712, P<\right.$ $0.01]$ without effect of either genotype $\left[\mathrm{F}_{(1,28)}=1.560\right.$, NS], or interaction between these two factors $\left[\mathrm{F}_{(9,252)}=0.803, \mathrm{NS}\right]$. In order to evaluate whether WT and $\mathrm{KO}$ mice showed differences in the reinforcing strength of the drug, a progressive ratio schedule was performed in mice achieving the acquisition criteria during the fixed ratio training. No significant differences were observed in the breaking points reached by $\mathrm{KO}$ and WT mice (Fig. 4B). These results indicate impairment in the acquisition of cocaine self-administration in GASP-1 KO mice. However those mutants reaching the acquisition criteria displayed similar reinforcing properties of cocaine than WT mice.

Increased down-regulation of striatal dopamine and muscarinic receptors in GASP-1 KO

GASP-1 has been proposed to mediate receptor down-regulation after chronic agonist treatment (Whistler et al., 2002; Bartlett et al., 2005; Tappe-Theodor et al., 2007). In order to investigate whether the difference observed between WT and GASP-1 KO animals in the acquisition of cocaine self-administration could be related to a differential numbers of dopamine and muscarinic receptors between both genotypes, we measured these respective binding sites in the striatum of WT and $\mathrm{KO}$ mice chronically exposed to cocaine. Untreated WT and $\mathrm{KO}$ mice expressed similar levels of dopamine and muscarinic receptors in the striatum (Table 1). As expected, WT animals displayed an important decrease in dopamine and muscarinic receptors after chronic self-administration of cocaine (Table 1). This down-regulation was even more pronounced in GASP-1 KO animals with an additional decrease of 39\% in $\mathrm{D}_{1}$-like receptors, 53\% in $\mathrm{D}_{2}$-like receptors and $31 \%$ in M-like receptors compared to WT mice (Table 1). These data are in agreement with previous studies suggesting a role of GASP-1 in down-regulation of GPCRs 
upon sustained stimulation. However, the present results indicate that GASP-1 would decrease rather than stimulate receptor down-regulation.

Mice exposed to the sensitization paradigm were also sacrificed on day 15 , after the last acute injection of cocaine or saline, and striatal dopamine and muscarinic receptor levels were assessed. No significant differences were found in receptor levels in any experimental group (Table 1). This negative result could be due to the mode of cocaine administration (passive versus active) or linked to the disruption of cocaine injection during five days before the last administration, which could allow the animals to recover their initial receptor levels.

\section{Discussion}

GASP-1 is a cytoplasmic protein predominantly expressed in the nervous system, which interacts with numerous GPCRs (Heydorn et al., 2004). Several lines of evidence suggest that GASP-1 is involved in the down-regulation of GPCRs upon chronic agonist stimulation and that disrupting the interaction between GASP-1 and GPCRs could improve in vivo receptor signalling upon sustained stimulation (Bartlett et al., 2005; Tappe-Theodor et al., 2007). However, these results are based on the use of high amounts of either antibody or truncated form of GASP-1, which could lead to nonspecific effects. In order to circumvent this problem, a mouse line in which GASP-1 gene has been disrupted by homologous recombination was generated. We present here the first characterization of GASP-1 KO mice in which the behavioural and biochemical consequences of acute and chronic cocaine administration were studied. We first assessed the

locomotor reactivity of GASP-1 KO vs. WT mice towards repeated exposure to a novel environment. We found no major alteration of the exploration propensity or anxiety levels 
in mutant mice. Only a slight decrease in the vertical locomotion was revealed in these mice. The mutants also showed normal learning and memory performance in a variety of tasks (Mathis et al; in preparation). In the absence of GASP-1, however, we observed a reduced locomotor response to cocaine and weaker sensitization as compared to WT mice. The rate of acquisition of cocaine self-administration was significantly impaired in the absence of GASP-1, since only $50 \%$ of GASP-1 deficient animals reached the acquisition criteria during the training period, while $86 \%$ of WT mice reached these criteria. However, cocaine reinforcing effects were similar in the WT mice and KO mice that achieved the acquisition criteria. Altogether, these data suggest an impairment of the acute and chronic behavioural responses to cocaine in the absence of GASP-1 and are at variance with the hypothesis that blunting the interaction of GASP-1 with GPCRs would increase the effect of agonist stimulation during chronic treatment (Bartlett et al., 2005; Tappe-Theodor et al., 2007).

Dopamine receptors are primary responsible for the locomotor and reinforcing effects of cocaine (see Koob \& Le Moal, 2006). Moreover, a secondary elevation of acetylcholine concentrations, due to dopamine activation, has been shown in the striatum following cocaine administration, which has been associated with its reinforcing effects (see Williams \& Adinoff, 2007). The literature describing the effects of repeated cocaine administration on striatal dopamine and muscarinic receptor densities reports contradictory results (either down-regulation, up-regulation or no alteration in receptor densities), depending on the dose, schedule and way of cocaine administration (contingent or non-contingent) (reviewed in Williams \& Adinoff, 2007). Here we report that cocaine self-administration induced a decrease in striatal dopamine and muscarinic receptor levels, consistent with an adaptive response to the chronic stimulation provoked by a contingent administration. This decrease was more severe in GASP-1 deficient mice than in their WT counterparts. This result is in agreement with a role of GASP-1 in 
postendocytic sorting of GPCRs and suggests that GASP-1 is positively implicated in the recycling rather than in the lysosomal sorting of these receptors at least when cocaine was contingently administered to the execution of an operant behaviour. A previous study has proposed that GASP-1 interacts specifically with $\mathrm{D}_{2}$ but not $\mathrm{D}_{1}$ receptors, and that this interaction results in the fast degradation of $\mathrm{D}_{2}$ receptors (Bartlett et al., 2005). Our data rather suggest that GASP-1 could interact in vivo with a broader range of GPCRs, including both fast and slow degrading receptors, and that this interaction would favour their recycling back to the plasma membrane in the case of a contingent administration of cocaine. The severe down-regulation of muscarinic receptors in the striatum of $\mathrm{KO}$ animals after cocaine self-administration is consistent with our previous observation showing that GASP-1 interacts in vitro with acetylcholine muscarinic $\mathrm{M}_{1}$ and $\mathrm{M}_{2}$ receptor subtypes (Simonin et al., 2004), and further supports a positive role of GASP-1 in receptor recycling.

Several lines of evidence from animal models and human neuroimaging studies suggest that chronic exposure to cocaine is associated with low striatal dopamine $\mathrm{D}_{2}$ receptor availability. Thus, $\mathrm{D}_{2}$ receptor densities were decreased in the striatum of nonhuman primates after chronic cocaine self-administration (Moore et al., 1998; Nader et al., 2002). In humans, positron emission tomography has shown persistent low striatal $\mathrm{D}_{2}$ receptor availability in chronic cocaine consumers (Volkow et al., 1993; Martinez et al., 2004). Despite of the decreased levels of $\mathrm{D}_{2}$-like receptors in the striatum of GASP-1 KO mice, the number of infusions and the motivational value of cocaine in the self-administration paradigm were not modified in those mutants acquiring cocaine self-administration. Interestingly, only half of the GASP-1 KO mice reached the acquisition criteria for cocaine self-administration. This impairment could be due to the decrease in the striatal $\mathrm{D}_{1}$-like receptors observed in GASP-1 KO mice, since the acquisition of cocaine self-administration was reported to be altered in $\mathrm{D}_{1}$ knockout mice. $\mathrm{D}_{1}$ 
receptors were also shown to be involved in the locomotor activating effects of cocaine (Cabib et al., 1991; Xu et al., 2000). The decreased locomotor effects observed after an acute cocaine administration in GASP-1 KO mice might therefore also be related to an alteration of $\mathrm{D}_{1}$ receptor signaling. Finally, we observed that the decrease in the rate of acquisition of cocaine self administration was also associated with a strong decrease in muscarinic receptors in GASP1 KO mice. These data are in agreement with recent findings showing that the local activation of muscarinic receptors in the nucleus accumbens core is necessary for acquisition of cocaine reinforcement (Crespo et al., 2006).

In conclusion our results point to GASP-1 as an important molecular component in the behavioural responses to cocaine treatment, and further support a potential role for this protein in postendocytic sorting and/or signaling upon sustained stimulation of GPCRs. Moreover, they suggest that GASP-1 could promote recycling rather than degradation of GPCRs, under these experimental conditions.

\section{Acknowledgements}

This work was supported by The Ministère de l'Education Nationale de l'Enseignement Supérieur et de la Recherche (MENSER) fellowship, The Association pour la Recherche sur le Cancer $\left(\mathrm{N}^{\circ} 3423\right)$, The Fondation pour la Recherche Médicale, The Centre National de la Recherche Scientifique, The Université de Strasbourg, The Ministerio de Educacion y Ciencia (SAF2007-64062), The Instituto de Salud Carlos III (RD06/001/001) "Ayudas para contratos posdoctorales de perfeccionamiento", Generalitat de Catalunya (20055GR00131) and ICREA. 
Acadmia. We thank The Institut de Génétique et de Biologie Moléculaire et Cellulaire core facilities for excellent technical assistance.

\section{Abbreviations}

ES cells, embryonic stem cells ; GASP-1, G protein-coupled receptor associated sorting protein1 ; GPCR, G protein-coupled receptor ; KO, knockout ; M-like, muscarinic-like ; WT, wild-type. 


\section{References}

Bartlett, S.E., Enquist, J., Hopf, F.W., Lee, J.H., Gladher, F., Kharazia, V., Waldhoer, M., Mailliard, W.S., Armstrong, R., Bonci, A. \& Whistler, J.L. (2005) Dopamine responsiveness is regulated by targeted sorting of D2 receptors. Proc Natl Acad Sci U S A, 102, 11521-11526.

Cabib, S., Castellano, C., Cestari, V., Filibeck, U. \& Puglisi-Allegra, S. (1991) D1 and D2 receptor antagonists differently affect cocaine-induced locomotor hyperactivity in the mouse. Psychopharmacology (Berl), 105, 335-339.

Castane, A., Valjent, E., Ledent, C., Parmentier, M., Maldonado, R. \& Valverde, O. (2002) Lack of $\mathrm{CB} 1$ cannabinoid receptors modifies nicotine behavioural responses, but not nicotine abstinence. Neuropharmacology, 43, 857-867.

Cong, M., Perry, S.J., Hu, L.A., Hanson, P.I., Claing, A. \& Lefkowitz, R.J. (2001) Binding of the beta2 adrenergic receptor to N-ethylmaleimide-sensitive factor regulates receptor recycling. J Biol Chem, 276, 45145-45152.

Crespo, J.A., Sturm, K., Saria, A. \& Zernig, G. (2006) Activation of muscarinic and nicotinic acetylcholine receptors in the nucleus accumbens core is necessary for the acquisition of drug reinforcement. J Neurosci, 26, 6004-6010.

Dombrowski, A.M., Jerkins, A.A. \& Kauffman, F.C. (1983) Muscarinic receptor binding and oxidative enzyme activities in the adult rat superior cervical ganglion: effects of 6hydroxydopamine and nerve growth factor. J Neurosci, 3, 1963-1970.

Fredriksson, R. \& Schioth, H.B. (2005) The repertoire of G-protein-coupled receptors in fully sequenced genomes. Mol Pharmacol, 67, 1414-1425. 
Heydorn, A., Sondergaard, B.P., Ersboll, B., Holst, B., Nielsen, F.C., Haft, C.R., Whistler, J. \& Schwartz, T.W. (2004) A library of 7TM receptor C-terminal tails. Interactions with the proposed post-endocytic sorting proteins ERM-binding phosphoprotein 50 (EBP50), Nethylmaleimide-sensitive factor (NSF), sorting nexin 1 (SNX1), and G protein-coupled receptor-associated sorting protein (GASP). J Biol Chem, 279, 54291-54303.

Hopkins, A.L. \& Groom, C.R. (2002) The druggable genome. Nat Rev Drug Discov, 1, 727-730.

Koob, G.F. \& Le Moal, M. (2006) Neurobiology of addiction. Academic Press, London.

Madras, B.K., Fahey, M.A., Canfield, D.R. \& Spealman, R.D. (1988) D1 and D2 dopamine receptors in caudate-putamen of nonhuman primates (Macaca fascicularis). J Neurochem, 51, 934-943.

Martinez, D., Broft, A., Foltin, R.W., Slifstein, M., Hwang, D.R., Huang, Y., Perez, A., Frankle, W.G., Cooper, T., Kleber, H.D., Fischman, M.W. \& Laruelle, M. (2004) Cocaine dependence and $\mathrm{d} 2$ receptor availability in the functional subdivisions of the striatum: relationship with cocaine-seeking behavior. Neuropsychopharmacology, 29, 1190-1202.

Martini, L., Waldhoer, M., Pusch, M., Kharazia, V., Fong, J., Lee, J.H., Freissmuth, C. \& Whistler, J.L. (2007) Ligand-induced down-regulation of the cannabinoid 1 receptor is mediated by the G-protein-coupled receptor-associated sorting protein GASP1. Faseb J, 21, 802-811.

Moore, C.A., Milano, S.K. \& Benovic, J.L. (2007) Regulation of receptor trafficking by GRKs and arrestins. Аппи Rev Physiol, 69, 451-482.

Moore, R.J., Vinsant, S.L., Nader, M.A., Porrino, L.J. \& Friedman, D.P. (1998) Effect of cocaine self-administration on dopamine D2 receptors in rhesus monkeys. Synapse, 30, 88-96. 
Nader, M.A., Daunais, J.B., Moore, T., Nader, S.H., Moore, R.J., Smith, H.R., Friedman, D.P. \& Porrino, L.J. (2002) Effects of cocaine self-administration on striatal dopamine systems in rhesus monkeys: initial and chronic exposure. Neuropsychopharmacology, 27, 35-46.

Simonin, F., Karcher, P., Boeuf, J.J., Matifas, A. \& Kieffer, B.L. (2004) Identification of a novel family of G protein-coupled receptor associated sorting proteins. J Neurochem, 89, 766775.

Tappe-Theodor, A., Agarwal, N., Katona, I., Rubino, T., Martini, L., Swiercz, J., Mackie, K., Monyer, H., Parolaro, D., Whistler, J., Kuner, T. \& Kuner, R. (2007) A molecular basis of analgesic tolerance to cannabinoids. J Neurosci, 27, 4165-4177.

Trigo, J.M., Panayi, F., Soria, G., Maldonado, R. \& Robledo, P. (2006) A reliable model of intravenous MDMA self-administration in naive mice. Psychopharmacology (Berl), 184, 212-220.

Trigo, J.M., Renoir, T., Lanfumey, L., Hamon, M., Lesch, K.P., Robledo, P. \& Maldonado, R. (2007) 3,4-methylenedioxymethamphetamine self-administration is abolished in serotonin transporter knockout mice. Biol Psychiatry, 62, 669-679.

Vassilatis, D.K., Hohmann, J.G., Zeng, H., Li, F., Ranchalis, J.E., Mortrud, M.T., Brown, A., Rodriguez, S.S., Weller, J.R., Wright, A.C., Bergmann, J.E. \& Gaitanaris, G.A. (2003) The G protein-coupled receptor repertoires of human and mouse. Proc Natl Acad Sci U S $A, \mathbf{1 0 0}, 4903-4908$.

Volkow, N.D., Fowler, J.S., Wang, G.J., Hitzemann, R., Logan, J., Schlyer, D.J., Dewey, S.L. \& Wolf, A.P. (1993) Decreased dopamine D2 receptor availability is associated with reduced frontal metabolism in cocaine abusers. Synapse, 14, 169-177.

Wallenstein, S., Zucker, C.L. \& Fleiss, J.L. (1980) Some statistical methods useful in circulation research. Circulation research, 47, 1-9. 
Wang, Y., Zhou, Y., Szabo, K., Haft, C.R. \& Trejo, J. (2002) Down-regulation of proteaseactivated receptor-1 is regulated by sorting nexin 1. Mol Biol Cell, 13, 1965-1976.

Weinman, E.J., Hall, R.A., Friedman, P.A., Liu-Chen, L.Y. \& Shenolikar, S. (2006) The association of NHERF adaptor proteins with $\mathrm{g}$ protein-coupled receptors and receptor tyrosine kinases. Аnпu Rev Physiol, 68, 491-505.

Whistler, J.L., Enquist, J., Marley, A., Fong, J., Gladher, F., Tsuruda, P., Murray, S.R. \& Von Zastrow, M. (2002) Modulation of postendocytic sorting of G protein-coupled receptors. Science, 297, 615-620.

Williams, M.J. \& Adinoff, B. (2007) The Role of Acetylcholine in Cocaine Addiction. Neuropsychopharmacology.

Xu, M., Guo, Y., Vorhees, C.V. \& Zhang, J. (2000) Behavioral responses to cocaine and amphetamine administration in mice lacking the dopamine D1 receptor. Brain Res, 852, $198-207$.

Xu, S.X., Hatada, Y., Black, L.E., Creese, I. \& Sibley, D.R. (1991) N-(pisothiocyanatophenethyl)spiperone, a selective and irreversible antagonist of D2 dopamine receptors in brain. $J$ Pharmacol Exp Ther, 257, 608-615.

Zhang, J., Zhang, L., Jiao, H., Zhang, Q., Zhang, D., Lou, D., Katz, J.L. \& Xu, M. (2006) c-Fos facilitates the acquisition and extinction of cocaine-induced persistent changes. $J$ Neurosci, 26, 13287-13296. 
Table 1. Dopamine and muscarinic receptor densities in the striatum of WT and $\mathrm{KO}$ mice subjected to a repeated cocaine treatment in sensitization and selfadministration paradigms

\begin{tabular}{|c|c|c|c|}
\hline \multirow[t]{2}{*}{ Receptors } & \multirow[t]{2}{*}{ Treatment } & \multicolumn{2}{|c|}{$\mathrm{Bmax} \pm \mathrm{SEM}(\mathrm{pmol} / \mathrm{mg})$} \\
\hline & & WT & $\mathrm{KO}$ \\
\hline \multirow[t]{3}{*}{$\mathrm{D}_{1}$-like } & Saline & $1.63 \pm 0.01$ & $1.89 \pm 0.18$ \\
\hline & Sensitization & $1.51 \pm 0.17$ & $1.48 \pm 0.30$ \\
\hline & Self-administration & $0.96 \pm 0.11 *$ & $0.58 \pm 0.13 * * *, \#$ \\
\hline \multirow[t]{3}{*}{$\mathrm{D}_{2}$-like } & Saline & $0.94 \pm 0.13$ & $1.05 \pm 0.19$ \\
\hline & Sensitization & $0.73 \pm 0.14$ & $0.81 \pm 0.02$ \\
\hline & Self-administration & $0.55 \pm 0.05 *$ & $0.26 \pm 0.08 * * *, \#$ \\
\hline \multirow[t]{3}{*}{ M-like } & Saline & $3.49 \pm 0.41$ & $3.89 \pm 0.50$ \\
\hline & Sensitization & $2.79 \pm 0.34$ & $3.09 \pm 0.38$ \\
\hline & Self-administration & $1.57 \pm 0.11 * * *$ & $1.10 \pm 0.15 * * *, \#$ \\
\hline \multicolumn{4}{|c|}{$* P<0.05$ and $* * * P<0.001$, cocaine-treated animals versus saline control } \\
\hline \multicolumn{4}{|c|}{ (assessed by one-way ANOVA). \# $P<0.05, \mathrm{KO}$ versus WT control (assessed } \\
\hline \multicolumn{4}{|l|}{ by $\mathrm{t}$ test) } \\
\hline
\end{tabular}




\section{Figure legends}

Figure 1. (A) Schematic diagram illustrating the WT Gpraspl allele, the targeting vector and the recombinant allele. Non-coding and coding exons are represented as open and filled boxes, respectively. 5' and 3' homology arms are shown as grey boxes. The 12.6-kb targeting vector includes the plasmid vector, the 5' and 3' homology arms and the neomycin-resistance (Neo) cassette. Length of restriction fragments used for the Southern blot analysis are denoted by arrows. Position of primers used for genotyping is shown with arrowheads. (B) representative results of Southern blot analysis of targeted neomycin-resistant clones. HindIII and BglIIdigested DNAs were hybridized with the Neo probe as shown in (A). (C) representative PCR genotyping analysis of homozygous and heterozygous mice offspring. A 288-bp fragment was amplified with the F1/R1 primer set, which is specific for the WT allele. A 710-bp fragment was amplified with the F2/R2 primer set, which is specific for the mutant allele. (D) western blot analysis of WT (+/+) and mutant (-/-) mice brain homogenates. The primary antibody recognized a $195-\mathrm{kDa}$ protein corresponding to GASP-1 and a 110-kDa protein corresponding to its closest homologue, GASP-2.

Figure 2. Sensitization to the locomotor effects of cocaine in WT and KO mice, protocol 1. Saline versus cocaine treatments are represented on the abscissa. Average locomotor activities + SEM in 1-h acquisition session are represented on the ordinate. Basal locomotor activity was determined by a saline injection (open bar). Daily cocaine $(20 \mathrm{mg} / \mathrm{kg}$, i.p.) or saline controlinjections began at day 1 until day 10, and locomotor activities were assessed at day 1, 4, 7 and 10. Sensitization was measured at day 15 with a challenging cocaine injection. \#\# $P<0.01$, day 1 
versus saline control; $* P<0.05$ and $* * P<0.01$ days versus day 1 (assessed by two-way ANOVA).

Figure 3. Sensitization to the locomotor effects of cocaine in WT and KO mice, protocol 2. Average + SEM activity scores in KO and WT mice on the first $h$ (data is shown in 20-min intervals) following saline and subsequent injections of cocaine at the doses of 10 and 20 mg/kg. In (A) number of beam interruptions. In (B) number of complete longitudinal translations between both cage extremities (cage crossings). $* P<0.05$ vs. previous injections (assessed by two-way ANOVA?); \# $P<0.05$ KO vs. WT mice (assessed by twoway ANOVA?); \$ $P<0.05$ vs. previous injections within the same 20 -min interval (assessed by two-way ANOVA?).

Figure 4. (A) Acquisition of cocaine self-administration in WT and GASP-1 KO mice. The session number is represented on the abscissa. Average nose-pokes + SEM in 2-h acquisition sessions under the fixed ratio 1 schedule are represented on the ordinate. Cocaine dose was 1.0 $\mathrm{mg} / \mathrm{kg}$ per injection during the acquisition. Filled circles show the data for reinforced nose-pokes (active hole) and open circles show the data for non-reinforced nose-pokes (inactive hole). Data with WT mice are represented on the left panel, and with GASP-1 KO mice on the right panel. (B) Reinforcing effects of cocaine in WT and GASP-1 KO mice. The breaking point achieved by WT (open bar) and GASP-1 KO (filled bar) mice under progressive ratio schedule for the dose they were trained on $(1.0 \mathrm{mg} /(\mathrm{kg} *$ injection $))$, are shown. Values represent group mean + SEM. * $P<0.05, * * P<0.01$ and $* * * P<0.001$, active versus inactive hole (assessed by two-way repeated measures ANOVA). 


\section{Supporting information}

Figure S1. In situ hybridization micrographs showing expression levels of Gprasp2 mRNA in brains of WT (A) and Gpraspl KO (B) mice.

Gprasp2 was expressed in the lateral septal (LS) area, down to the diagonal band of Broca and in the ventral pallidum, in WT (A) and Gpraspl KO (B) mice. Gprasp2 mRNA was also detected in the shell of the nucleus accumbens along the medial aspect of the anterior commissure (ac). Gprasp 2 mRNA positive cells were observed in the globus pallidus (GP), at the interface of the caudate putamen $(\mathrm{CPu})$ and the GP, whereas very few cells expressed Gprasp2 mRNA in the $\mathrm{CPu}$ of both genotypes (C,D). Scale bar $=100 \mu \mathrm{m}$.. 


\section{Cocaine $20 \mathrm{mg} / \mathrm{kg}$, ip}
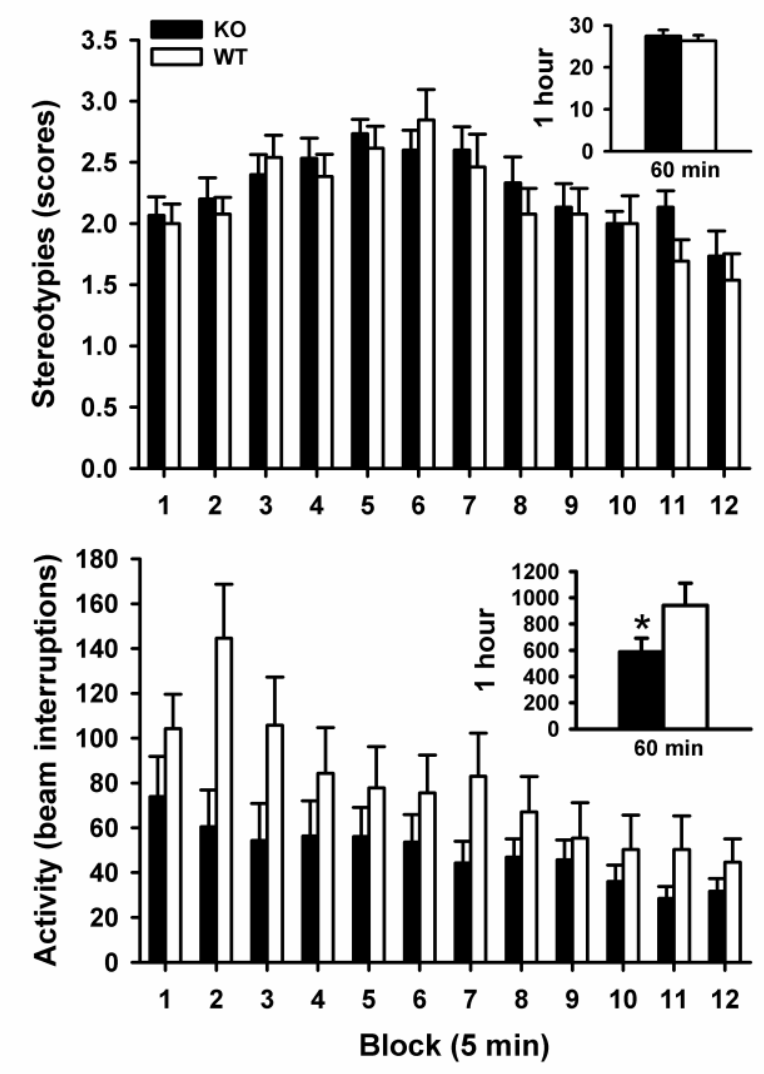

Figure S2. Evaluation of stereotypies.

Average + SEM of the appearances of stereotypic behaviours during 20-s intervals every 5 min after the injection of $20 \mathrm{mg} / \mathrm{kg}$ cocaine (top) and of the activity scores that were recorded in parallel (bottom). Histograms correspond to the average scores over the 1-h recording period. * $P$ $<0.05$ vs WT mice (assessed by one-way ANOVA?). The activity levels were substantially larger than following the previous injection of $20 \mathrm{mg} / \mathrm{kg}$ cocaine. Part of this difference may be due to the presence in the vicinity of the cages of two experimenters who evaluated the stereotypies during the entire recording session or/and may reflect further sensitization. 
Methods

Non-radioactive in situ hybridization

Adult GASP-1 KO and WT control mice (n=3 per group) were sacrificed and their brains were dissected out, postfixed and embedded in polyethylene glycol as described previously (Klosen $e t$ al., 1993). Brain serial coronal sections ( $8 \mu \mathrm{m}$ thick) were mounted on SuperFrost slides (Menzel-Gläzer, Fisher Scientific Bioblock, Illkirch, France) and postfixed for $10 \mathrm{~min}$ at room temperature in $4 \%$ phosphate-buffered formaldehyde, rinsed in phosphate buffer saline and digested for $30 \mathrm{~min}$ at $37^{\circ} \mathrm{C}$ with $2 \mu \mathrm{g} / \mathrm{ml}$ proteinase $\mathrm{K}$ (Roche Applied Science, Meylan, France) in phosphate buffer saline. Proteinase $\mathrm{K}$ digestion was stopped with $2 \%$ phosphate-buffered formaldehyde for $5 \mathrm{~min}$ on ice. After three washes in phosphate buffer saline for $10 \mathrm{~min}$ each, sections were acetylated twice for $10 \mathrm{~min}$ in $100 \mathrm{mM}$ triethanolamine, $0.25 \%$ acetic anhydride. After two 10-min rinses in phosphate buffer saline, sections were equilibrated in $5 \mathrm{x}$ SSC, $0.05 \%$ Tween-20 before hybridization. Hybridization was performed for $40 \mathrm{~h}$ at $54^{\circ} \mathrm{C}$ with $200 \mathrm{ng} / \mathrm{ml}$ labeled sense or antisense probes in 50\% formamide, $5 \times$ SSC, $5 \times$ Denhardt's solution and 500 $\mu \mathrm{g} / \mathrm{ml}$ salmon sperm DNA. Stringency rinses were performed 6 times for 10 min in $0.1 \times$ SSC at $72^{\circ} \mathrm{C}$. Digoxigenin-labeled bound probes were detected with alkaline phosphatase-labeled antidigoxigenin antibodies (Roche Applied Science, Meylan, France). Alkaline phosphatase activity was detected with bromo-chloro-indolyl phosphate and nitroblue tetrazolium in the presence of 5\% polyvinyl alcohol (70,000-100,000 MW; Sigma, Saint-Quentin Fallavier, France). 